\title{
ФОРМУВАННЯ СИСТЕМИ КОНТРОЛЮ НА СУЧАСНОМУ ПІДПРИЕМСТВІ
}

Постановка проблеми. В ринкових умовах господарювання зростає значення функції контролю. Контроль стає необхідним, по-перше, для усунення невизначеності інформації про ситуацію, що склалась на підприємстві; по-друге, для попередження можливості виникнення пов'язаних $з$ цією невизначеністю кризових ситуацій; і по-третє, для забезпечення та постійного підтримання умов успішної діяльності підприємства. Серед найбільш поширених в сучасних умовах форм та способів контролю можна назвати управлінський облік, внутрішній аудит та контролінг.

Найбільш досконалою формою організації контролю на підприємстві $\epsilon$ запровадження контролінгу як функціонально відокремленого напрямку економічної роботи на підприємстві. Контролінг включає в себе встановлення мети підприємства, поточний збір та обробку інформації для прийняття управлінських рішень, здійснення функцій контролю відхилень фактичних показників діяльності підприємства від планових, а також підготовку рекомендацій для прийняття управлінських рішень. Координуючи, інтегруючи та спрямовуючи діяльність усієї системи управління підприємством на досягнення поставлених цілей, контролінг виконує функцію “управління управлінням" і являє собою синтез планування, обліку, контролю, економічного аналізу, організації інформаційних потоків тощо.

Аналіз останніх досліджень i публікацій. Дослідженню проблеми організації системи контролінгу присвячено безліч наукових робіт вітчизняних та зарубіжних авторів (Хан Д., Хорват П., Вебер Ю., Аніскін Ю.П., Ананькіна Є.А., Данілочкіна Н.Г., Фольмут Х.Й., Харін А.А., Коленський І.Л., Пущенко I.H., Кармінський А.М., Примак А.Г., Фалько С.Г., Одегов Ю.Г., Ніконова Ю.Г., Воронін В.П. та ін.). Однак у більшості наукових досліджень мало уваги приділено теоретичним основам формування фінансового контролінгу. Тому проблема економічної сутності контролінгу носить актуальний характер у сучасних умовах.

Виділення невирішених частин загальної проблеми. Незважаючи на доволі вагомі наукові напрацювання, існуюча система в повній мірі не відповідає сучасним вимогам у зв'язку 3 недосконалістю нормативного, організаційно-методичного забезпечення внутрішнього контролю витрат, відсутністю внутрішніх стандартів. Тому на сучасному етапі важливим $\epsilon$ подальше дослідження 3 метою пошуку нових підходів до формування системи внутрішнього контролю в управлінні витратами підприємства.

Формування цілей статті. Метою статті $€$ дослідження сутності та значення контролю у системі управління витратами, визначення організаційних форм внутрішнього контролю, принципів i методів усієї сукупності фінансових, економічних, організаційних, оперативнотехнічних і фактичних способів та прийомів контролю витрат підприємств. 
Виклад основного матеріалу дослідження й обгрунтовування одержаних наукових результатів.. Для задоволення оперативних потреб управління виробництвом діюча система контролю повинна бути організована як за видами діяльності підприємства, так і за центрами відповідальності та місцями виникнення витрат.

Під час здійснення контролю на підприємстві потрібно визначити його мету, безпосередні завдання і функції та враховувати фактори, що впливають на організацію контролю, принципи.

Основна мета внутрішнього контролю витрат полягає в наданні інформації про відхилення від норм та нормативів, виявленні «вузьких» місць на виробництві, визначенні невикористаних резервів на підприємстві. Можна виділити основні завдання внутрішнього контролю витрат виробництва:

- зниження використання основних та допоміжних матеріалів на продукцію;

- зменшення матеріаломісткості та енергомісткості продукції, що виробляється;

- зниження рівня загальновиробничих витрат;

- недопущення браку та погіршення якості продукції.

Мета і завдання служби внутрішнього контролю залежать від розміру, структури підприємства, технічного рівня управління, організаційної структури управління, розподілу посадових обов'язків, складу аналітичної служби та потреб керівництва. При визначенні суб'єктів внутрішнього контролю доцільним є розподіл їх на групи: суб'єкти, до функціональних обов'язків яких входить лише здійснення контрольної діяльності (відділ технічного контролю, контрольно-ревізійний відділ): суб'єкти, до функціональних обов'язків яких входять здійснення як контролю, так і виконавчої діяльності (бухгалтерська служба); суб'єкти, до функціональних обов'язків яких контрольна діяльність не включена, проте здійснюється через виробничі потреби підприємства (начальники служб, підрозділів, майстри технологічного обладнання); суб'єкти, що виконують контрольні функції для реалізації власних завдань управління виробничими витратами (планово-економічний відділ, відділ праці і заробітної плати).

Здійснення контролю потребує розроблення певної стратегії перевірки для уникнення повторних перевірок, мінімізації витрат часу та високої якості роботи. Тому доцільно створювати децентралізовані відділи контролю в різних сферах діяльності підприємства, які підпорядковуються керівнику відповідного спеціального підрозділу (виробничий контролер, контролер служби збуту). При такій організації внутрішнього контролю досягається єдність методологічного забезпечення контролю, чіткий розподіл праці контролера-аналітика, інженератехнолога, внутрішнього аудитора, інтеграція інформації, отриманої 3 інших систем підтримки управління на основі застосування сучасних технологій обробки інформації.

Наявність штатної одиниці інженератехнолога у складі відділу контролю обумовлюється необхідністю участі кваліфікованих спеціалістів у плануванні та контролі рівня виробничих витрат, оскільки визначення складу й обсягу витрат - не суто економічне, а технічно-економічне завдання.

До функціональних обов'язків контролерів належать: збір аналітичної інформації у розрізі центрів відповідальності, обробка аналітичної інформації в розрізі центрів відповідальності, обробка й узагальнення результатів контролю, контроль дотримання нормативів витрат та аналіз відхилень від норми, складання управлінської звітності, модифікації контрольної інформації для розроблення рекомендацій щодо обгрунтування управлінських рішень. 
Умовою, що забезпечує цілісність системи контролю, є дотримання принципу технологічного поділу контролю на етапи: попередній, поточний (оперативний) та заключний.

Попередній контроль - оцінка господарської операції перед іiї здійсненням 3 точки зору доцільності, законності на відповідність дотримання нормативних документів. Такий контроль $є$ найбільш дієвим для попередження нераціонального використання ресурсів, дотримання нормативів витрачання сировини в процесі переробки. Аналіз беззбитковості виробництва продукції має стати основними прийомами попереднього контролю. Функціями попереднього контролю $\epsilon$ : складання кошторисів накладних витрат підрозділів; закріплення відповідальних за їх дотриманням; розроблення прогресивних норм матеріалів i трудових витрат; визначення оптимального розміру витрат.

Поточний (оперативний) контроль оперативне виявлення і своєчасне усунення порушень і відхилень, що виникають в процесі виконання господарських операцій i виробничих завдань. Для оперативного контролю витрат важливим $є$ безперервне, суцільне й систематичне документування всіх господарських операцій та фактів. Поточний (оперативний) контроль витрат має бути організований таким чином, щоб він охоплював усі сторони системи інформаційного забезпечення - вміщувати не тільки норми та нормативи, а й організацію технологічних процесів, нормування, планування й облік зміни норм, аналіз їхньої ефективності, а також забезпечувати реальну, своєчасну оцінку стану й перспектив розвитку підприємства при найменших витратах.

Заключний контроль - виявлення неякісних за критеріями законності та доцільності документів, а також визначення ступеня їх впливу на достовірність інформації, узагальненої у звітності.
Під час проведення контролю рекомендується застосовувати різноманітні методи, які $\epsilon$ сукупністю фінансових, економічних, організаційних, оперативнотехнічних i фактичних способів та прийомів 3 перевірки витрат підприємств. Для документального оформлення результатів проведення контролю витрат необхідно використовувати спеціально розроблені робочі документи, зокрема тести внутрішнього контролю облікового процесу витрат, аналітичні тести перевірки правильності відображення витрат у статтях калькуляції виробничої собівартості.

Ефективність заключного етапу (етапу узагальнення та реалізація результатів контролю) повинна забезпечити: аналітичність контрольних даних, визначену на попередньому етапі, розподіл відхилень витрат на виробництво за причинами їх виникнення, групування та кодування виявлених порушень за масштабом та впливом на господарський процес, системний зв'язок відхилень витрат на виробництво 3 центрами відповідальності, винними у порушеннях, посилання на документ, що містить слідчоюридичне обгрунтування вини конкретних виконавців.

Організація внутрішнього контролю не $\epsilon$ жорстко регламентованою, а визначається внутрішнім стандартом в межах окремого підприємства. Під внутрішнім стандартом слід розуміти документи, що деталізують і встановлюють регламенти для здійснення та узагальнення результатів контролю, прийняті i затверджені керівництвом підприємства. Стандарт внутрішнього контролю в управлінні витратами підприємства визначає регламенти формування та узагальнення контрольної інформації i використання результатів внутрішнього контролю для прийняття управлінських рішень за такими напрямами:

- формування контрольної інформації; 


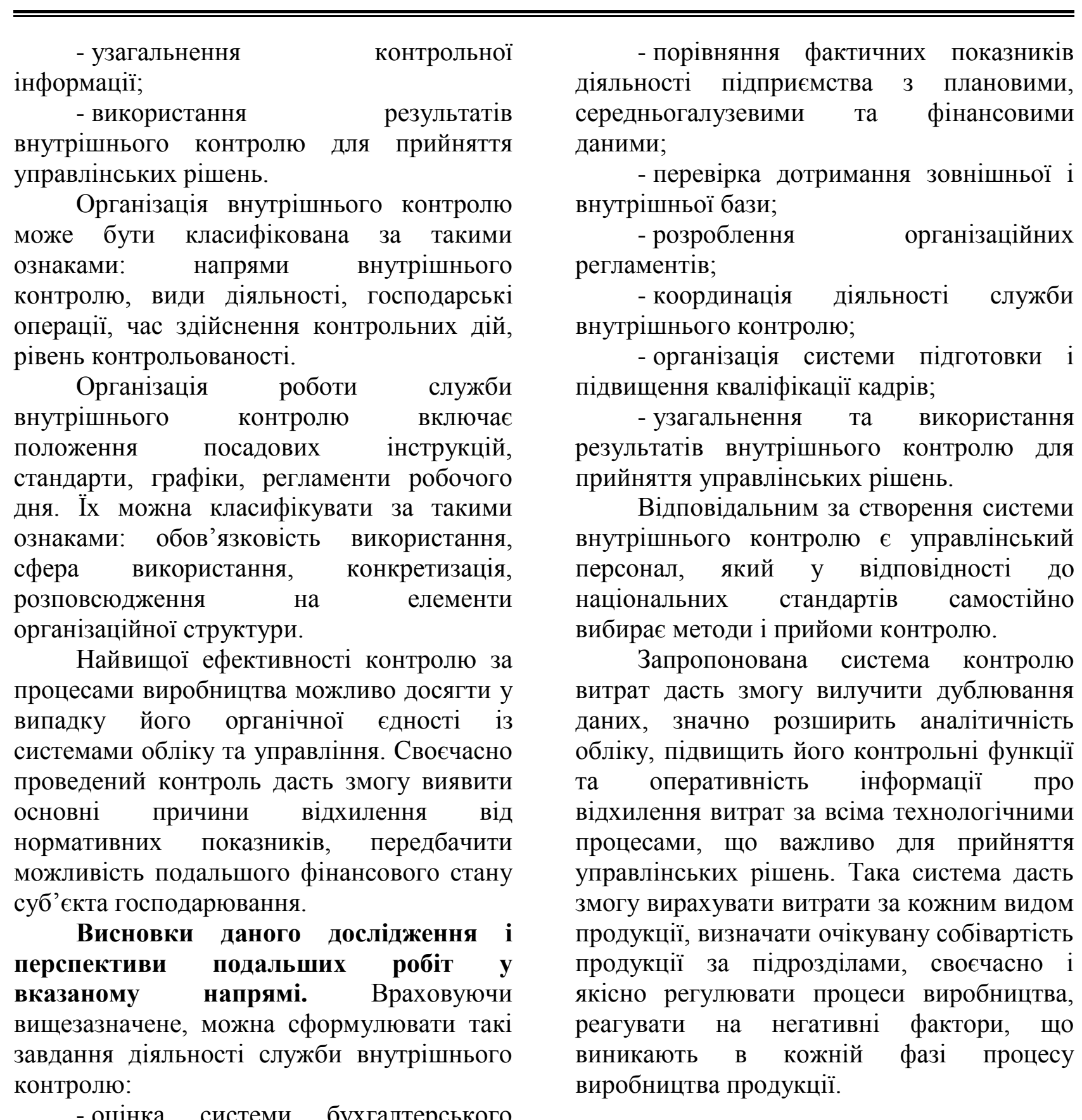
обліку та контролю на підприємстві;

\section{Список літератури}

1. Хан, Д. Планирование и контроль: концепции контроллинга [Текст]: пер. с нем. /Д. Хан; под ред. и с предисл. А.А. Турчака, Л.Г. Головача, М.Л. Лукашевича. - М.: Финансы и статистика, 1997. - 800 с.

2. Давидович, I.Є. Управління витратами [Текст]: навч. посібник / I.Є. Давидович. - К.: Центр учбової літератури, 2008. - 320 с.

3. Анискин, Ю.П. Планирование и контроллинг [Текст]: учеб. по специальности «Менеджмент организации» / Ю.П. Анискин, А.М. Павлова. - 2-е изд. - М.: Омега-Л, 2005. $280 \mathrm{c}$. 
4. Ананькина, Е.А. Контроллинг как инструмент управления предприятием [Текст] / Е.А. Ананькина, С.В.Данилочкин, Н.Г. Данилочкина; под ред. Н.Г. Данилочкиной. - М.: ЮНИТИ, 2002. - 279 с.

4. Моссаковський, В. Система контролю витрат виробництва за сучасних умов [Текст] / В. Моссаковський // Бухгалтерський облік і аудит. - 2002. - № 9. - С. 225.

6. Зосименко, Т.І. Концептуально-методичні основи вітчизняного та іноземного досвіду управління витратами [Електронний ресурс] / T.I. Зосименко. - Режим доступу: http://www.nbuv.gov.ua/portal/natural/Vcndtu/Ekon/2009_35/21.htm.

Ключові слова: контролінг, система контролінгу, функція, мета, процес управління, управління підприємством.

\section{Анотації}

Проведено аналіз теоретичних підходів до визначення поняття «контролінг», розглянуто його цілі, завдання та функції. Обгрунтовується необхідність вдосконалення системи контролю на підприємстві.

Проведен анализ теоретических подходов относительно определения понятия «контроллинг», рассмотрены его цели, задачи и функции. Обосновывается необходимость совершенствования системы контроля на предприятии.

The article analyzes the theoretical approaches on the definition of "controlling", considered the objectives, tasks and functions. The necessity of improving the control systems in the enterprise. 